\title{
Anatomical and Morphological Stem Features of two Haloxylon Species (Chenopodiaceae Vent.) of Drought Stress, Kazakhstan
}

\author{
Alina Zhaglovskaya ${ }^{1 *}$, Saule Aidosova ${ }^{1}$, Nursulu Akhtayeva ${ }^{1}$, \\ Asem Mamurova ${ }^{1}$ and Dinara Yesimova ${ }^{2}$ \\ ${ }^{1}$ Faculty of Biology and Biotechnology, Al-Farabi Kazakh National University, \\ Al Farabi Avenue 71, 050038 Almaty, Kazakhstan. \\ ${ }^{2}$ Faculty of Chemical Technology and Natural Sciences, S. Toraighyrov \\ Pavlodar state university, Lomova street, 64, 140008, Pavlodar, Kazakhstan.
}

DOI: http://dx.doi.org/10.13005/bbra/1863

(Received: 16 September 2015; accepted: 25 October 2015)

The territory of Kazakhstan lies mainly in zones of deserts and semideserts. Soil degradation is all over the territory as a result of human intervention in vegetation. The representatives of Chenopodiaceae Vent. genus (Haloxylon aphyllum Minkw., Haloxylon persicum Bng.) are natural sandbinders in northern deserts of Kazakhstan. This article concerns adaptation traits of plants of drought stress. The article states the anatomical and morphological characteristics of representatives of Chenopodiaceae family: Haloxylon aphyllum, Haloxylon persicum. It was identified that there are similarities and differences in the anatomy of the stem of both species. The main difference is the number of layers of the epidermis: one layer in Haloxylon aphyllum, 2 layers in $H$. persicum, size of epidermis, chlorenchyma, parenchyma. Comparative characteristics of the two species of Haloxylon show some features of adaptation of psammophytes (Haloxylon persicum) and halophytes (Haloxylon aphyllum). Increased size of epidermal tissue and chlorenchyma of Haloxylon persicum stem, as well as increased size of parenchyma and crystalliferous cells of Haloxylon aphyllum. Features of the anatomical structure of the vegetative organs of plants adequately reflect their adaptation to growing conditions. Studied species are plants- $\mathrm{C}_{4}$, by type of $\mathrm{CO}_{2}$ fixation, as a mechanism of adaptation to hot and dry climate. Haloxylon persicum is regarded as a genetic derivative to H. aphyllum.

Key words: Haloxylon aphyllum Minkw., Haloxylon persicum Bng., ecological adaptation, psammophyte, halophyte, epidermis.

Big part of Central Asia lies in arid and semiarid zones. In Kazakhstan $70 \%$ of territory is prone to desertification (Eisfelder et al., 2012, 2013; Lioubimtseva and Adams, 2004; Lioubimtseva at al., 2005, 2009).

Soil degradation and desertification are main ecologic issues of this country. Therefore, Kazakhstan is an important object of study (ADB, 2010). Environmental degradation was defined as one of major threats by High Level Panel on

\footnotetext{
* To whom all correspondence should be addressed. Tel.: +7 70561185 91;

E-mail: Alina.Zhaglovskaya@gmail.com
}

Threats, Challenges and Change, United Nations Organization (Eisfelder, 2014).

As a result of high rates of desertification it is necessary to restore disturbed lands and provide ecological recovery of natural vegetation. The main purpose of restoration is to use viable populations. It will help to restore functions and processes of ecosystems, prevent erosion and protect biological diversity (Bradshaw, 1987).

It is widely accepted that efficiency of ecological restoration depends on the selection of local plants, especially in stress conditions (Knapp and Rice, 1994; Linhart, 1995; Lesica and Allendorf, 1999). 
Chenopodiaceae family includes about 100 genera and more than 1500 species which are broadly spread on arid and subtropical lands (Heywood, 1978). Haloxylon (Chenopodiaceae Vent.) genus comprises 10 species where on the territory of CIS countries and in semideserts of Central Asia there are only 3 species (Haloxylon aphyllum Minkw., Haloxylon persicum Bng., Haloxylon ammodendron C.A. Mey. Bunge. Haloxylon aphyllum (local name-Black saxaul) and Haloxylon persicum (local name -White saxaul) have a vast growing area in deserts of Iran-Turanian region and Arab peninsula. Haloxylon ammodendron can be only found in the east of Kazakhstan and in Junggar province. This species mainly grow in the area of the Gobi Desert in Central Asia (Lavrenko, 1962).

Saxaul forests directly affect environmental situation creating favorable conditions for human life and farming. Owing to natural domination saxaul can be considered as ecologically key species. Saxaul forests serve the following functions of ecosystem: biomass production, sand stabilization; minimization of soil drifting; microclimate mitigation which ensures growth and development of associated plants (for example, Carex physodes M. Bieb.); setting habitat conditions for animals. And, desert forests are a food supply for farming and energy-efficient biofuel for local population (Buras et al., 2012).

Currently, as a result of human impact it was identified that saxaul is spread only on $25 \%$ of potential areal in Kazakhstan. About three thirds of potential areal of saxaul forests were destroyed or they deteriorated comparing to potential areal (Thevs et al., 2013).

Having studied for many years growth of Haloxylon, its development, morphology, and seed germination it became possible to identify a number of special features of its biology. The sources contain much information about morpho-biological study of Haloxylon aphyllum (Ol'shevskii, 1935).

Chenopodiaceae family consists of a big number of C4 species where dominant plants of deserted territories of Kazakhstan hold a specific place. Many researchers studied anatomy structure of this genus (Kadereit et al., 2003; Pyankov et al., 1999, 2000; Sage et. al., 1999; Sage 2001; Su Pei-Xi, 2005; Ramazannejad, 2006; Zhibin, 2011; Heklau, 2012).
A big number of Chenopodiaceae stem anatomy descriptions was published by Gregory (1994, 2009). Plenty anatomy researches belong to Russian scientists (Arcichovskij \& Osipov, 1934; Butnik, 1983; Vasilevskaja, 1955, 1965; Novruzova \& Chapari, 1974; Timonin 1987a \& b).

In order to provide theoretical basis for recommendations on restoration of natural ecosystems in deserted areas and provision of stability of natural ecosystems it is necessary to study the anatomy structure of green stems of two species of Chenopodiaceae genus (Haloxylon aphyllum, $H$. persicum), analysis of similarities and differences of morphometric indices and adaptabilities of the species under study.

\section{MATERIALSAND METHODS}

The research was carried out on the territory of Ili-Balkhash region, situated within the borders of Almaty city region, Balkhash-Alakol hydro-ecological region (Fig.1). The material of the research was collected in the framework of experimental fieldworks carried out on the territory of Almaty city region in Ile-Balkhash region, valley of the Ili River during summer time.

Four plots were examined on the territory of the Ili River estuary. A representative of Chenopodiaceae family (Haloxylon persicum) was collected on plots I and II. Haloxylon aphyllum was gathered as a research material on plots III and IV (Table 1).

According to soil and geomorphological, climatic, and geobotanical conditions the territory under study belongs to coastal salt plain region. Relief of the territory is typically hummocky and contains ridges, melting into plain and hills. Among hills and ridges there are quite high ridges (10-20 $\mathrm{m}$ ) and quite low sand deposits up to $10 \mathrm{~m}$ high. Spots of dry-type playas are found where hills and ridges are considered as occasional sand hills ( 0.5 $-2.5 \mathrm{~m}$ high). Dry beds and drainless lowlands are typical to Bakanass plain. According to soilgeographical regionalization the territory belongs to the zone of grey-brown soils which in their turn belong to modern desert crust soils (Gvozdeva, 1960).

The climate is extremely continental. The moderate temperature of the coldest month of the year (January) in ten years varies between minus 
11 and minus 13 degrees Celsius. In the hottest month of the year (July) the moderate temperature is plus 26 degrees Celsius. The duration of frostfree season is 153 days. The annual amount of atmospheric sediments is not more than $200 \mathrm{~mm}$. The moderate degree of saturation is $61 \%$. Winds blow predominantly from the east. Average wind speed is $2.5 \mathrm{~m} / \mathrm{s}$ (Bedarev, 1985).

The dominant species of vegetation is Haloxylon aphyllum. The following wood and shrub species are also there: Halimodendron halodendron, Populus deversifolia, Calligonum aphillum, Eurotia ceratoides, Astragalus ammodendron, etc. Artemisia terrae albae, Stipa Hohenackeriana, Agropurum sibiricum and some other of them are typical species of grass vegetation. The grass canopy consists of Artemisia solgorica, Echinopa albicalis, etc. Considerable part of the grass canopy is represented by ephemeral plants (Bedareva, 2009).

Experimental trees were selected according to age and other evaluation indices. Thus, there was measured height of experimental tree, its crown diameter, root collar diameter, as well as stand density and ground water level (GWL) (Table 2) were identified. In order to do a morpho- anatomical structure study samples were taken from at least three trees of each species.

Plants were botanized and fixed for structure analysis. Fixation was done in $70 \%$ spirit by Strasburger-Flemming technique (spirit, glycerin, water 1:1:1). Anatomic specimens were prepared by means of microtome with TOC-2 freezing device. Slices were mounted into glycerin in accordance to conventional procedures (Prozina, 1960; Permyakov, 1988; Barykina et al., 2004). Anatomic slices were 10-15 micron thick. In order to do quantitative analysis morphometric indices were taken by means of software for micrography. Photomicrographs were taken with MC-300 microscope $($ Zoom $\times 180)$. For statistical data processing mathematical statistics method and Microsoft Excel were applied.

\section{RESULTSAND DISCUSSION}

Table 3 shows similarities and differences of saxaul species. It is based on published data and research works of different scientists (Ol'shevskii, 1935; Gvozdeva, 1960; Lavrenko, 1962; Bedareva, 2009).

Analysis of morphological characteristics

Table 1. Information about the plots

\begin{tabular}{|c|c|c|c|c|c|}
\hline Plot & Name of species & $\begin{array}{l}\text { Region under } \\
\text { study }\end{array}$ & Coordinates & $\begin{array}{l}\text { Landscape } \\
\text { type }\end{array}$ & $\begin{array}{l}\text { Analysis of } \\
\text { anthropogenic } \\
\text { effect }\end{array}$ \\
\hline I & Haloxylon persicum & Kazakhstan, Almaty & $45^{\circ} 21 \mathrm{~N}^{\circ} 4^{\circ} 28 \mathrm{E}$ & Hilled ridges & Moderate \\
\hline II & & $\begin{array}{l}\text { city region, Ili-Balkhash } \\
\text { region, valley of the } \\
\text { Ili River }\end{array}$ & $45^{\circ} 24 \mathrm{~N} 74^{\circ} 25 \mathrm{E}$ & Alluvial sands & $\begin{array}{l}\text { Sand barchans of } \\
\text { human origin }\end{array}$ \\
\hline III & Haloxylon aphyllum & & $45^{\circ} 02 \mathrm{~N} 74^{\circ} 43 \mathrm{E}$ & Salt plain & Low \\
\hline IV & & & $45^{\circ} 05 \mathrm{~N} 74^{\circ} 37 \mathrm{E}$ & Inter-ridge & $\begin{array}{l}\text { Light forest of } \\
\text { saxaul, cut-over land }\end{array}$ \\
\hline
\end{tabular}

Table 2. Growing condition, evaluation indices of experimental trees

\begin{tabular}{|c|c|c|c|c|c|c|c|}
\hline S & \multicolumn{4}{|c|}{ Evaluation indices of an experimental tree } & \multirow{2}{*}{$\begin{array}{l}\text { GWL } \\
{[\mathrm{m}]}\end{array}$} & \multirow{2}{*}{$\begin{array}{l}\text { Stand } \\
\text { density } \\
\text { [tree/ha] }\end{array}$} & \multirow{2}{*}{ Associated species of plants } \\
\hline No. & $\begin{array}{l}\text { Age } \\
\text { [years] }\end{array}$ & $\begin{array}{l}\text { Height } \\
{[\mathrm{m}]}\end{array}$ & $\begin{array}{l}\text { Root collar } \\
\text { diameter }[\mathrm{cm}]\end{array}$ & $\begin{array}{l}\text { Crown } \\
\text { diameter }[\mathrm{m}]\end{array}$ & & & \\
\hline I & $8 \pm 2.3$ & $0.7 \pm 0.3$ & $5-6 \pm 3.1$ & $1.2 \pm 0.3$ & 7.5 & 1000 & Carex physodes M. Bieb., \\
\hline II & $18 \pm 2.7$ & $1.5 \pm 0.2$ & $8 \pm 4.8$ & $1.4 \pm 0.2$ & 8 & 1500 & Eremurus inderiensis Regel. \\
\hline III & $20 \pm 4.3$ & $3.0 \pm 0.2$ & $20 \pm 3.9$ & $2 \pm 0.5$ & 4.6 & 950 & Krascheninnikovia ceratoides L. \\
\hline IV & $5-6 \pm 2.3$ & $0.5 \pm 0.3$ & $4 \pm 2.4$ & $0.8 \pm 0.2$ & 3.7 & 780 & $\begin{array}{l}\text { Gueldenst., Artemisia terrae-albae } \\
\text { Krasch. }\end{array}$ \\
\hline
\end{tabular}


Table 3. Comparative morphological characteristics of Haloxylon genus types

\begin{tabular}{|c|c|c|c|c|c|}
\hline $\begin{array}{l}\text { S. } \\
\text { No. }\end{array}$ & $\begin{array}{l}\text { Morphological } \\
\text { characteristic }\end{array}$ & Haloxylo & phyllum (Minkw.) Iljin & $\begin{array}{l}\text { Haloxyl } \\
\text { ex Bois }\end{array}$ & $\begin{array}{l}\text { rsicum Bunge } \\
\text { Buhse }\end{array}$ \\
\hline 1 & Taxonomy & $\begin{array}{l}\text { phylum } \\
\text { class } \\
\text { order } \\
\text { family } \\
\text { genus } \\
\text { specie }\end{array}$ & $\begin{array}{l}\text { Magnoliophyta } \\
\text { Magnoliopsida } \\
\text { Caryophyllales } \\
\text { Chenopodiaceae } \\
\text { Haloxylon } \\
\text { aphyllum (Minkw.) } \\
\text { Iljin }\end{array}$ & $\begin{array}{l}\text { phylum } \\
\text { class } \\
\text { order } \\
\text { family } \\
\text { genus } \\
\text { specie }\end{array}$ & $\begin{array}{l}\text { Magnoliophyta } \\
\text { Magnoliopsida } \\
\text { Caryophyllales } \\
\text { Chenopodiaceae } \\
\text { Haloxylon } \\
\text { persicum Bunge ex } \\
\text { Boiss. \& Buhse }\end{array}$ \\
\hline 2 & Life-form & Small tre & & Large sl & \\
\hline 3 & Size & From 2-5 & Ip to 8-10 m tall & $4-5(6)$ & \\
\hline 4 & $\begin{array}{l}\text { Root collar } \\
\text { diameter }\end{array}$ & $50-60 \mathrm{~cm}$ & $20-30 \mathrm{~cm}$ & & \\
\hline 5 & Root system & $\begin{array}{l}\text { It is up to } \\
\text { soils, } 7.3 \\
\text { hummoc } \\
\text { deep in s } \\
\text { undergro }\end{array}$ & $\begin{array}{l}\mathrm{m} \text { long in alkaline } \\
\text { ong in partly fixed } \\
\text { sands, and up to } 10 \mathrm{~m} \\
\text { with deep } \\
\text { water deposits }\end{array}$ & $\begin{array}{l}\text { Root sy } \\
\text { root, an }\end{array}$ & $\begin{array}{l}\text { s lateral or with a tap } \\
\text { o } 10-11 \text { m deep }\end{array}$ \\
\hline 6 & Trunk & $\begin{array}{l}\text { Bark is d } \\
\text { of high d } \\
\text { darker co }\end{array}$ & $\begin{array}{l}\text {-grey. Wood is heavy, } \\
\text { ity, short grain, and of } \\
\text { in the center }\end{array}$ & $\begin{array}{l}\text { Bark is } \\
\text { is hard, }\end{array}$ & $\begin{array}{l}\text { h or light-grey. Wood } \\
\text { grain, unmanageable }\end{array}$ \\
\hline 7 & Stems & $\begin{array}{l}\text { Sappy, di } \\
\text { acidic to }\end{array}$ & $\begin{array}{l}\text { green, bent, faintly } \\
\text { te }\end{array}$ & $\begin{array}{l}\text { Fresh sp } \\
\text { to taste }\end{array}$ & re dryish, pale-green, bitter \\
\hline 8 & Leaves & $\begin{array}{l}\text { Leaves a } \\
\text { primordi } \\
\text { curly wh }\end{array}$ & $\begin{array}{l}\text { pposite and reduced to } \\
\text { ase of leaves has short } \\
\text { hair }\end{array}$ & $\begin{array}{l}\text { Leaves } \\
\text { shaped } \\
\text { white gl }\end{array}$ & $\begin{array}{l}\text { ry small, with delta- } \\
\text {, awl-shaped, with } \\
\text { brim }\end{array}$ \\
\hline 9 & Flowers & $\begin{array}{l}\text { Flowers a } \\
\text { solitary, b } \\
\text { scale-like } \\
\text { than a flo } \\
\text { glumace } \\
\text { stamens. } \\
\text { stigmas }\end{array}$ & $\begin{array}{l}\text { small-seized, bisexual, } \\
\text { ed in axils of small } \\
\text { aves which are shorter } \\
r \text { itself. Bracts have } \\
\text { edges. Flowers have } 5 \\
\text { ary has } 4-5 \text { fugacious }\end{array}$ & $\begin{array}{l}\text { Flowers } \\
\text { or mult } \\
\text { Periant } \\
\text { rounde } \\
\text { stamen }\end{array}$ & $\begin{array}{l}\text { sexual, plain, solitary } \\
\text { aving two small bracts. } \\
\text { umaceous, with } 5 \\
\text { lars. There are } 5 \\
\text { le has 2-5 short stigmas }\end{array}$ \\
\hline 10 & Fruit & $\begin{array}{l}\text { Type - D } \\
\text { Strophio } \\
\text { Fruit is it } \\
\text { have rou } \\
\text { Seeds are }\end{array}$ & $\begin{array}{l}\text { Seed } \\
\text { Wings. } \\
\text { essed on top. Wings } \\
\text { d or cuneate roots. } \\
\text { tt, with spiral embryo }\end{array}$ & $\begin{array}{l}\text { Type - I } \\
\text { Strophic } \\
\text { Fruit is } \\
\text { fleshy I } \\
\text { embryc }\end{array}$ & $\begin{array}{l}\text { eed } \\
\text { Vings. } \\
\text { oid, winged, slightly } \\
\text { contains planispiral } \\
\text { hing in testa }\end{array}$ \\
\hline 11 & Habitat & $\begin{array}{l}\text { Modern } \\
\text { estuaries } \\
\text { sand ridg } \\
\text { form hea }\end{array}$ & $\begin{array}{l}\text { ancient valleys and } \\
\text { rivers; degradations of } \\
\text { it forms heavy bed } \\
\text { bed }\end{array}$ & $\begin{array}{l}\text { Sand de } \\
\text { sands, } \\
\text { tops of }\end{array}$ & $\begin{array}{l}\text { predominantly in } \\
\text { ssion beds, banks and } \\
\text { hummocks. It does not }\end{array}$ \\
\hline 12 & $\begin{array}{l}\text { Ecological } \\
\text { group }\end{array}$ & $\begin{array}{l}\text { Xerophy } \\
\text { halophyt } \\
\text { salt-toler } \\
\text { aphyllum }\end{array}$ & $\begin{array}{l}\text { ight demander, } \\
\text { sammophyte } \\
\text { than Haloxylon }\end{array}$ & $\begin{array}{l}\text { Typical } \\
\text { demanc }\end{array}$ & $\begin{array}{l}\text { mophyte, strong light } \\
\text { ought-tolerant, less }\end{array}$ \\
\hline 13 & Uses & Feeding, & hnical & Rock an & nent, sand stabilizing \\
\hline
\end{tabular}


shows the following common factors: Haloxylon genus types are quite similar in structure of stems, leaves, fruits. Species differ in life-forms and ecological conditions of habitat. Comparative analysis of Haloxylon persicum and Haloxylon aphyllum shows specific adaptation traits of psammophytes and halophytes. All these traits determine adaptation of plants to conditions of halomorphic and alkaline soils.

As a psammophyte and halophyte, Haloxylon aphyllum grows in ancient valleys of rivers, in degradations of sand ridges, takyr-like soils, and stabilized sands. Whereas Haloxylon persicum grows in more severe conditions: in sand deserts, sandy soils, unfixed sands, and tops of sand hummocks.

Transverse sections of green stems were used for identification of similarities and differences between Haloxylon aphyllum and Haloxylon persicum on anatomic level (Fig. 2).

According to the analysis of received data, transverse section of a stem consists of epidermis, palisade chlorenchyma, parenchyma cells, and vascular cylinder.

Cuticle covers stem from outside protecting it from mechanical defects and extreme temperatures. Epidermis consists of one $(H$. aphyllum) or two layers (H. ðersicum) of cells. Epidermis serves specific functions and is characterized not only by micromorphologic form of stem but also by protection function for palisade chlorenchyma cells.

However, different number of epidermic layers probably depends on severe growth conditions of Haloxylon persicum (two layers of epidermal cells). Therefore, water loss decreases and stems become tougher. Hypodermis layer comes after epidermis. It serves mechanical function. Hypodermis layer of Haloxylon aphyllum is distinct and is developed in entire layer (Fig. 3, 4). Owing to several layers of epidermis Haloxylon persicum has hypodermis not as an entire layer but as single inclusions (Fig. 5, 6).

Palisade chlorenchyma layer follows epidermis cells. It is well known that essential and mostly common feature that is acquired in the process evolutionary adaptation to dry environment conditions is reduction of lamina. However, number of layers of mesophyll increases in plants. Palisade tissue becomes especially well

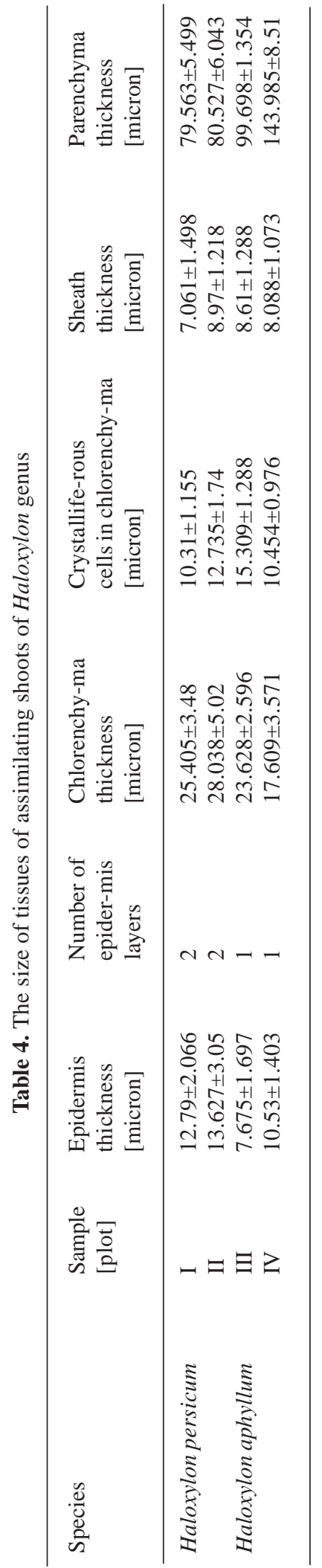


developed what allows plants to resist first of all soil drought (Vasilevskaya, 1955). Increasing number of layers and also density of palisade tissue in some ways balances small seize of photosynthetic organs. But on the other side, having small area for photosynthesis plants have to get macronutrients. This happens due to development of palisade parenchyma from the both side of stem. As palisade tissue is the most highly-productive type of tissue and it makes main contribution to photosynthesis (Vasilevskaya, 1965).

Further on, there is a layer of cells of vascular bundle sheath (kranz anatomy). Saxaul leaves are reduced very much, and annual fresh stems serve main $\mathrm{C}_{4}$ photosynthetic function (Pyankov et al., 1999). These stems have the same origin as true induviae (apical meristem of shoot apex) (Fahn and Arzee, 1959). Carbon dioxide fixation takes place in chloroplasts of mesophyll as a result of $\mathrm{CO}_{2}$ addition to phosphoenolpyruvate producing the four-carbon acids - oxaloacetate and malate. This is a ' carbon fixation pathway'. plants grow in southern regions and are adapted to hot and dry climate (Pyankov et al., 1999).

Conducting bundles fuse among themselves creating complete central cylinder. Pith consists of big passage parenchyma cells. Layer of parenchyma cells, as well as chlorenchyma contains crystalliferous cells (druses). Salt crystals are considered metabolic-waste products of plant bodies, especially in xerophytes. Probably, crystals favor increase of osmotic pressure of enchylema (Fig. 5, 6).

Vascular cylinder includes xylem and phloem. In Haloxylon persicum types xylem vessels are symmetrized having cambium sheath. While xylem vessels of Haloxylon aphyllum are not symmetrized and cambium sheath appears as entire layer, both species of Haloxylon genus have sclerenchyma in vascular cylinder.

Specific features of anatomy structure of vegetative organs of plants including stem organization quite clearly show the way they are adaptive to growth conditions.

Though Haloxylon persicum and Haloxylon aphyllum grow in similar habitats and are members of one ecological group of psammophytes, they have similarities as well as obvious differences in anatomy structure.

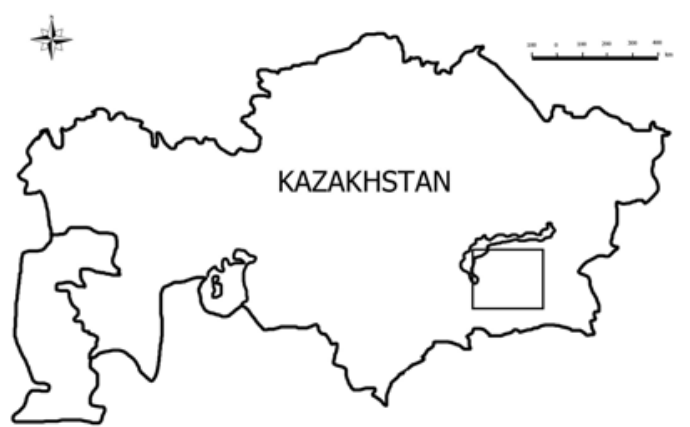

Fig. 1. Location of the study area
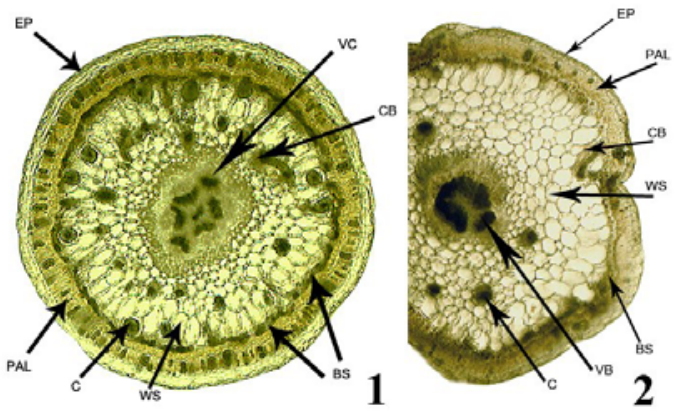

Fig. 2. Comparative anatomy structure of assimilating shoots of Haloxylon persicum (1), Haloxylon aphyllum (2). EP- epidermis, PAL - palisade chlorenchyma, $\mathrm{C}$ - crystalliferous cells, BS - cells of vascular bundle sheath, WS -water storage tissue, VC - vascular cylinder, $\mathrm{CB}$ - cortical bundle, VB - vascular bundle

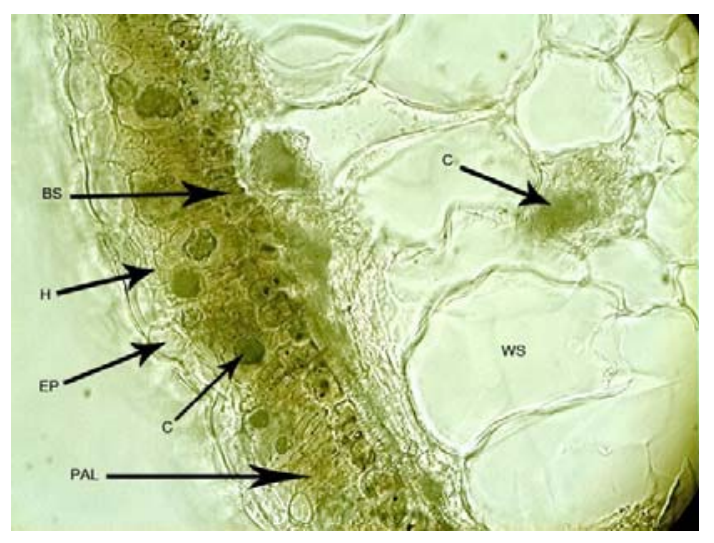

Fig. 3. Anatomy structure of assimilating shoots of H. aphyllum. EP- epidermis, H- hypodermis, PALpalisade chlorenchyma, C - crystalliferous cells, BScells of vascular bundle sheath, WS - water storage tissue, VC - vascular cylinder, CB - cortical bundle, VB - vascular bundle, S - sclerenchyma 
The following features are common ones for the majority of psammophytes:

1. stem form (rounded);

2. crystalliferous cells in parenchyma;

3. entire chlorenchyma, crystals in chlorenchyma;

4. elongated parenchyma cells around vascular cylinder;

5. cortex cells;

6. vascular cylinder, 4 different layers, every vascular bundle is surrounded with thick layer of sclerenchyma cells;

7. well developed palisade parenchyma;

8. well developed sclerenchyma.

The main distinction of saxaul species is a number of epidermis layers, size of epidermis, chlorenchyma, parenchyma (Table 4). Epidermic layer thickness increases due to epidermal differention of Haloxylon persicum. Haloxylon persicum has epidermis layer 12.79 - 13.62 micron thick comparing to $H$. aphyllum with 7.67-10.53 micron. Increase of number of epidermis layers defines ecologic valence of species to severe temperature conditions. Chlorenchyma size of Haloxylon persicum (25.405-28.038 micron thick) is bigger than one of $H$. aphyllum (17.609-23.628 micron thick). Chlorenchyma is a tissue functioning in photosynthesis in species of Haloxylon genus which according to the structure and nature of chemical activity during fixation corresponds to type of photosynthesis. The general concept of pathway is that it is possessed by evolutionarily younger taxons which have high temperature optimum of photosynthesis, high rates of light saturation, and water use efficiency (Shamsutdinov, Ubaidullayev and Shamsutdinova, 2014). According to V.I. Pyankov (Shamsutdinov, Pyankov, et al, 2014) number of plants (in a row: barchans sands - stabilized sands - takyr-like soils - saline soils) has increased from $16.5 \%$ to $70 \%$. The same row shows deterioration of soil conditions: increase of water deficiency, degradation of soil agrophysical properties, salt content rise.

Parenchyma thickness varies in species. Thus, Haloxylon aphyllum has higher thickness of parenchyma layer (99.69 - 143.98 micron) than Haloxylon persicum does (79.56 - 80.52 micron). Probably, the reason is that $H$. aphyllum grow in more favorable conditions where underground waters run close to the surface. As a result of more available moisture water-storing tissue of stems develops better. Also, high number of crystalliferous cells in anatomy structure of stems of Haloxylon aphyllum is explained by more saltaffected habitat than one of Haloxylon persicum.

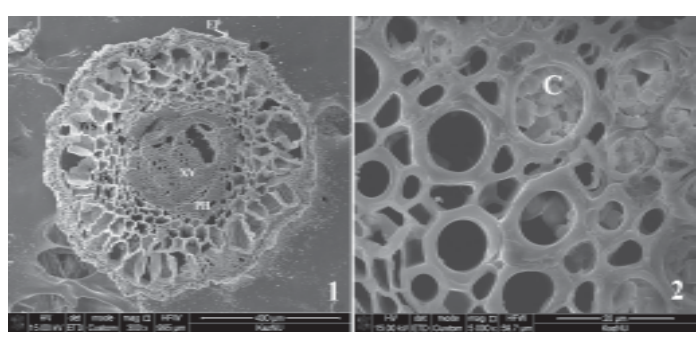

Fig. 4. Scanning electronic microscope microphotograph of anatomy of $H$. aphyllum assimilating shoots (1), arrangement of crystalliferous cells in cortical bundle (2). EPepidermis, PAL - palisade chlorenchyma, $\mathrm{S}$ - water storage tissue, $\mathrm{CB}$ - cortical bundle, $\mathrm{PH}$ - phloem, XY- xylem, C - crystalliferous cells

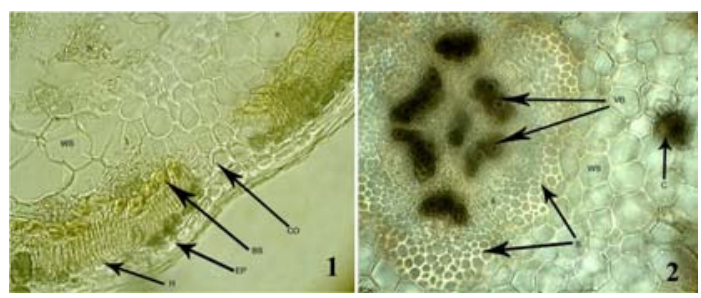

Fig. 5. Anatomy structure of assimilating shoots of $H$. persicum (1), Vascular cylinder of stem (2). EPepidermis, $\mathrm{H}$ - hypodermis, $\mathrm{PAL}$ - palisade chlorenchyma, C - crystalliferous cells, BS - cells of vascular bundle sheath, WS - water storage tissue,

CB - cortical bundle, Ñ̂̃ - collenchyma, VB vascular bundle, $\mathrm{S}$ - sclerenchyma

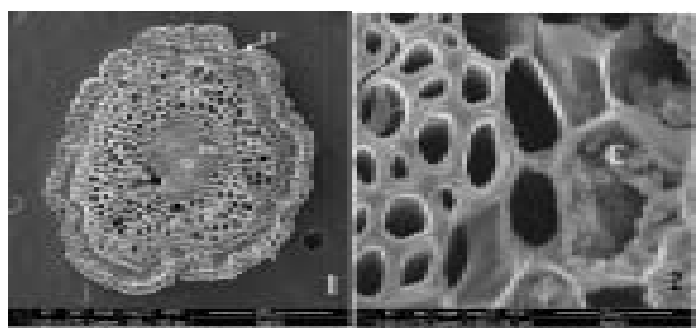

Fig. 6. Scanning electronic microscope microphotograph of anatomy of $H$. persicum assimilating shoots (1), arrangement of crystalliferous cells in water storage tissue (2). EP- epidermis, PAL palisade chlorenchyma, $\mathrm{S}$ - water storage tissue, CB cortical bundle, $\mathrm{PH}$ - phloem, XY- xylem, $\mathrm{C}$ crystalliferous cells 
It stands salty level of underground waters (up to $40 \mathrm{gr} / \mathrm{l}$ ) and in terms of mineral accumulation rate it belongs to group of plants for alkaline soil (sodium) (Rodin, 1963).

According to I.P.Petrov (Petrov, 1936) ecologic differences of white and Haloxylon aphyllum are based on edaphic factors. Therefore, specific nature of their distribution on the territory is not a consequence of world zonation but a result of edaphic differences of habitat.

L.Ya.Kurochkina (1978) agrees with Petrov's point of view and considers formations of white and Haloxylon aphyllum forests as 'ecologic-phytocenotic variants' (psammophytic, halomesoxerophytic and petrophytic) which replace each other in different ecologic conditions. For this reason she assigns them under one vegetation type.

The outstanding association of Haloxylon persicum forests with sand nonsaline substratum allows to consider Haloxylon persicum as a genetic derivative of $H$. aphyllum, its ecologically specific blind branch (Bykov, 1968) which features rest in physiological and anatomy characters. Haloxylon persicum has three layers of epidermis, deeply buried stomatal mechanisms, and high osmotic pressure. These factors ensure drought-resistance of this species comparing to $H$. aphyllum, and widespread occurrence of Haloxylon persicum in sand massifs (Rachkovskaya et al., 2003).

Consistent identification of functional and structural features of plants allows to project climatic habitat and potential environmental opportunities. This approach can be applied both for projection of changes of vegetation under changing climate and development of highefficiency agrophytocenoses in different natural and climatic zones (Shamsutdinov, Pyankov et al., 2014).

The best possible spatial combination of plants taking into consideration their phonological rhythms and mechanisms of adaptation to cycles of drought and soil salinity provides guarantee to higher plants to survive and to accumulate biomass on degraded grazing lands. Coexistence of droughtresistant species in accordance to a wide range of salt content in combination with limited water quantity is an essential factor in development of landscape design and methods of rehabilitation of degraded grazing lands suffered from salt in soils (Shuyskaya, 2012).

\section{CONCLUSIONS}

Studied species are plants-, by type of fixation, as a mechanism of adaptation to hot and dry climate. Different number of epidermic layers probably depends on severe growth conditions of Haloxylon persicum (two layers of epidermal cells). Therefore, water loss decreases and stems become tougher. Hypodermis layer comes after epidermis. Parenchyma thickness varies in species. Haloxylon aphyllum has higher thickness of parenchyma layer than Haloxylon persicum does. The reason is that $H$. aphyllum grow in more favorable conditions where underground waters run close to the surface. Layer of parenchyma cells, as well as chlorenchyma contains crystalliferous cells (druses). This feature is considered as a mechanism for adaptation to saline soils. Thus, the results of the research can become a framework and evidence of possibility to create a culture to be more resistant in sense of vegetative reclamation and to have more broad ecologic variability.

Thus, the results of the research can become a framework and evidence of possibility to create a culture to be more resistant in sense of vegetative reclamation and to have more broad ecologic variability.

\section{REFERENCES}

1. Eisfelder, C., Kuenzer, C., Dech, S. Derivation of biomass information for semi-arid areas using remote sensing data. Int. J. Remote Sens., 2012; 339: 2937-2984.

2. Eisfelder, C., Kuenzer, C., Dech, S., Buchroithner, M.F. Comparison of two remote sensing based models for regional net primary productivity estimation a case study in semiarid Central Kazakhstan. IEEE J. Sel. Top. Appl. Earth Obs. Remote Sens., 2013; 64: 1843-1856.

3. Lioubimtseva, E., Adams, J.M. Possible implications of increased carbon dioxide levels and climate change for desert ecosystems. Environ. Manag., 2004; 331: 388-404.

4. Lioubimtseva, E., Cole, R., Adams, J.M., Kapustin, G. Impacts of climate and land-cover changes in arid lands of Central Asia. J. Arid. Environ., 2005; 622: 285-308.

5. Lioubimtseva, E., Henebry, G. Climate and 
environmental change in arid Central Asia, impacts, vulnerability, and adaptations. J. Arid. Environ., 2009; 73: 963-977.

6. ADB. Central Asia Atlas of Natural Resources Asian Development Bank. Manila, Philippines, ISBN, 2010; 978-971-561-886-1.

7. Eisfelder, C., Klein, I., Niklaus, M., Kuenzer, C. Net primary productivity in Kazakhstan, its spatio-temporal patterns and relation to meteorological variables. Journal of Arid Environments, 2014;103: 17-30.

8. Bradshaw, A.D. The reclamation of derelict land and the ecology of ecosystems. In: Restoration ecology, a synthetic approach to ecological research (Jordan WR, Gilpin ME, Aber JD, ed). Cambridge: Cambridge University Press, 1987; pp 53-83.

9. Knapp, E.E., Rice, K.J. Starting from seed, genetic issues in using native grasses for restoration. Restoration Management Notes, 1994; 12: 40-45.

10. Linhart, Y.B. Restoration, revegetation, and the importance of genetic and evolutionary perspectives. In: Proceedings of the Wildland Shrub and Arid Land Restoration Symposium (Roundy BA, McArthur ED, Haley JS, Mann DK, ed). Las Vegas: Nevada, 1995; 271-287.

11. Lesica, P., Allendorf, F.W. Ecological genetics and the restoration of plant communities, mix or match? Restoration Ecology, 1999; 7: 42-50.

12. Heywood, V.H. Flowering Plnats of the world. London: Grom Gelm, 1978.

13. Lavrenko, E.M. Osnovnye cherty botanicheskoj geografii pustyn’ Evrazii i Severnoj Afriki. Moslow: Izd-vo AN SSSR, 1962 [in Russian].

14. Buras, A., Wucherer, W., Zerbe, S., Z. Noviskiy and N. Muchitdinov. Allometric variability of Haloxylon species in Central Asia. For. Ecology and Management, 2012; 274: 1-9.

15. Thevs, N., W. Wucherer and A. Buras. Spatial distribution and carbon stock of the Saxaul vegetation of the winter-cold deserts of Middle Asia. J. of Arid Environments, 2013; 90: 29-35.

16. Ol'shevskii, V.V. Raspredelenie i razvitie saksaula. Problemy rastenievodcheskogo osvoenija pustyn', 1935; 4: 78-91 [in Russian].

17. Kadereit, G., Borsch, T., Weising, K., Freitag, H. Phylogeny of Amaranthaceae and Chenopodiaceae and the evolution of C 4 photosynthesis. Int. J. Plant Sci., 2003; 164: 959-986.

18. Pyankov, V.I., Black Jr., C.C., Artyusheva, E.G., Voznesenskaja, E.V., Ku, MSB., Edwards, G.E. Features of photosynthesis in Haloxylon species of Chenopodiaceae that are dominant plants in Central Asian deserts. Plant Cell Physiol., 1999;
40: $125-134$.

19. Pyankov, V.I., Gunin, P.D., Tsoog, S., Black, C.C. C 4 plants in the vegetation of Mongolia, their natural occurrence and geographical distribution in relation to climate. Oecologia, 2000; 123: 15-31.

20. Sage, R.F., Li, M.R., Monson, R.K. The taxonomic distribution of C 4 photosynthesis. In: C 4 Plant Biology (Sage RF, Monson RK, ed). San Diego: Academic Press, USA, 1999; pp 551-584.

21. Sage, R.F. Environmental and evolutionary preconditions for the origin and diversiûcation of the C 4 photosynthetic syndrome. Plant Biol., 2001; 3: 202-213.

22. Su Pei-Xi, An Li-zhe, Ma Rui-Jun and Liu XinMin. Kranz anatomy and c4 photosynthetic characteristics of two desert plants, Haloxylon ammodendron and Calligonum mongolicum. Acta phytoecologica Sinica, 2005; 291: 1-7.

23. Ramazannejad, Ghadi, D. Azizian and M. Assadi. Comparative anatomical analysis of stem in four genera of the tribe Salsoleae, Chenopodiaceae. Iran Journ. Bot., 2006; 122: 169-182.

24. Zhibin Wen, Mingli Zhang. Anatomical types of leaves and assimilating shoots and carbon 13 C/ 12 C isotope fractionation in Chinese representatives of Salsoleae sl Chenopodiaceae. Flora, 2011; 206: 720-730.

25. Heklau, H., Gasson, P., Schweingruber, F. and P. Baas. Wood anatomy of Chenopodiaceae Amaranthaceae sl. IAWA Journal, 2012; 332: 205-232.

26. Gregory, M. Bibliography of systematic wood anatomy of dicotyledons. IAWA Journal Suppl., 1994; 1: 1-266.

27. Gregory, M., I. Poole and E.A. Wheeler. Fossil dicot wood names, an annotated list with full bibliography. IAWA Journal Suppl., 2009; 6: 1220.

28. Arcichovskij, V. and A.P. Osipov. Saksaul, opredelenie ego vozrasta i ego fiziologicheskich osobennostej. Sov. Bot., 1934; 2: 28-52 [in Russian].

29. Butnik, A.A. Charakteristika tipov anomal'nogo polikambial'nogo vtorichnogo utolshchenija osevych organov vidov semejstva Chenopodiaceae. Bot. Zh., 1983; 65: 572-580 [in Russian].

30. Vasilevskaya, V.K. Osobennosti stroenija afill'nyh kserofitov. Izvestiya AN TurkmSSR., 1955; 3: 35-43 [in Russian].

31. Vasilevskaya, V.K. Strukturnye prisposoblenija rastenij zharkih i holodnyh pustyn' Srednej Azii i Kazahstana. Probl. sovremennoj botaniki, 
1965; 2: 5-17 [in Russian].

32. Novruzova, Z.A. and N.M. Chapari. Formirovanie anatomicheskoj structury predstavitelej marevych. Dokl AN AZSSR, 1974; 30: 59-62 [in Russian].

33. Timonin, A.K. Anomal'noe utolscenie osevych organov centrosemennych na primere Amaranthaceae Juss. 1 Koncepcii utolshchenija osobennosti utolshchenija otdel'nych vidov. Bjull Mosk obshchestva ispyt. prirody, otd boil., 1987a; 92: 63-81[in Russian].

34. Timonin, A.K. Anomal'noe utolshchenie osevych organov centrosemennych na pri-mere Amaranthaceae Juss. 2 Evoljucionnye aspekty. Bjull Mosk obshchestva ispyt prirody, otd boil., 1987b; 92: 92-103[in Russian].

35. Gvozdeva, L.P. Rastitel'nost' i kormovye resursy pustyni Sary-Ishikotrau. Alma-Ata, 1960 [in Russian].

36. Bedarev, S.A. Pogoda i pastbishha (opyt prognozirovanija v uslovih Kazahstana). Kainar, Alma-ata, 1985 [in Russian].

37. Bedareva, O.M. Jekosistemy srednih pustyn' Kazahstana i ih inventarizacija metodami distancionnogo zondirovanija. Dissertation, Kaliningrad State Technical University, 2009 [in Russian].

38. Prozina, M.L. Botanicheskaja mikrotehnika. Moskow, 1960 [in Russian].

39. Permyakov, A.I. Mikrotehnika: Uchebn.-metod. Posobie dlja slushatelej FPK i stud. Biol.fak. MGU. Moskow: Moscow State University Press, 1988 [in Russian].

40. Barykina, R.P., Veselova, T.D., Devyatov, A.G., Jalilova, H.H., Ilyina, G.M., Chubatova, N.V. Spravochnik po botanicheskoj mikrotehnike. Osnovy i metody. Moskow: Moscow State University Press, 2004 [in Russian].

41. Fahn, A., Arzee, T. Vascularization of articulated Chenopodiaceae and the nature of their fleshy cortex. Am. J. Bot., 1959; 46: 330-338.
42. Shamsutdinov, Z.Sh., Sh.R. Ubaidullayev and N.Z. Shamsutdinova. Sredoobrazujushhaja rol' galofitov i ee rol' $\mathrm{v}$ povyshenii produktivnosti aridnyh pastbishhnyh system. Sbornik nauchnyh trudov. Mnogofunkcional'noe adaptivnoe kormoproizvodstvo: Sredoobrazujushhie funkcii kormovyh rastenij i jekosistem, 2014; 3(51): 85-98 [in Russian].

43. Shamsutdinov, Z.Sh., Pyankov, V.I., Khamidov, A.A., Shamsutdinova, E.Z. Jekologofiziologicheskij podhod $k$ identifikacii vnutrividovoj jekotipicheskoj organizacii aridnyh kormovyh rastenij. Sbornik nauchnyh trudov. Mnogofunkcional'noe adaptivnoe kormoproizvodstvo: Sredoobrazujushhie funkcii kormovyh rastenij i jekosistem, 2014; 3(51): 100-110 [in Russian].

44. Rodin, L.E. Rastitel'nost' pustyn' Zapadnoj Turkmenii. Problemy osvoenija pustyn', 1963; 1: 89-124 [in Russian].

45. Petrov, M.P. Ob jekologii solonchakovogo i peschanogo saksaulov. Voprosy jekologii $i$ biocenologii, 1936; 3: 101-158 [in Russian].

46. Kurochkina, L. Ya. Psammofil'naja rstitel'nost' Kazahstana. Kainar, Alma-Ata [in Russian].

47. Bykov, B.A., 1968. O proishozhdenii peschanoj rastitel'nosti Srednej Azii i Kazahstana. Problemy osvoenija pustyn', 1978; 1: 34-65 [in Russian].

48. Rachkovskaya, E.I., E.A. Volkova and V.N. Hramcova. Botanicheskaja geografija Kazahstana i Srednej Azii (v predelah pustynnoj oblasti). Sankt-Peterburg, 2003 [in Russian].

49. Shuyskaya, E., Rajabov, T., Matsuo, N., Toderich, K., Gismatullina, L., Voronin, P., Yamanaka, N. Seasonal Dynamics of Asiatic Desert C 3 /C 4 Species Related to Landscape Planning and Rehabilitation of Salt Affected Lands. Journal of Arid Land Studies, 2012; 221: 77-82. 